\begin{tabular}{|c|c|}
\hline ISSN $=1980-993 X-$ doi:10.4136/1980-993X \\
www.agro.unitau.br/ambi-agua \\
E-mail: ambi-agua@agro.unitau.br \\
Phone.: +55 (12) 3625-4212
\end{tabular}

\title{
Good practices for scientific publication
}

\author{
(http://dx.doi.org/10.4136/ambi-agua.182) \\ Getulio Teixeira Batista \\ Professor of the Master Degree Program in Environmental Sciences of the University of Taubaté, SP \\ E-mail: ambi-agua@agro.unitau.br
}

\begin{abstract}
In this editorial, the principles of a scientific publication, the editorial procedures and communication guidelines between authors and the Ambiente \& Água journal's Editorial Committee are discussed in order to improve the publication pipeline. Ambi-Agua is a completely open access journal, with no charges for submission, editing or publication and it is in a consolidation phase with just five years of circulation. Our staff is restricted to a few people that work part time in the journal sharing their task with several other chores imposed by their jobs at the University of Taubaté. Additional support to cover doi ${ }^{\mathrm{TM}}$ registration, Internet domain and hosting is granted by the Institute for Environmental Research in Hydrographic Basins (IPABHi). Therefore, it is important that communication is kept in a smooth and efficient way to maximize productivity.
\end{abstract}

Keywords: Ambi-Agua; author's guidelines; Open Journal Systems (OJS); Public Knowledge Project (PKP); SEER; environment; water.

\section{Boas práticas para publicação científica}

\section{RESUMO}

Neste editorial, os princípios de uma publicação científica, os procedimentos editoriais e diretrizes de comunicação entre autores e o Comitê Editorial da revista Ambiente \& Água são discutidos, a fim de melhorar o fluxo de publicação. A Ambi-Agua é uma revista de acesso totalmente aberto, sem custos de submissão, de edição ou publicação e se encontra em fase de consolidação, com apenas cinco anos de circulação. Nossa equipe está restrita a poucas pessoas que trabalham em tempo parcial na revista e partilham suas tarefas com várias outras impostas pelo trabalho na Universidade de Taubaté. O Instituto de Pesquisas Ambientais em Bacias Hidrográficas (IPABHi) tem dado apoio financeiro para cobrir o registro do doi ${ }^{\mathrm{TM}}$, domínio de Internet e a hospedagem do sistema editorial eletrônico. Portanto, é importante que a comunicação seja mantida de forma cordial e eficiente para maximizar a produtividade.

Palavras-chave: Ambi-Agua; diretrizes para autores; Open Journal Systems (OJS); Public Knowledge Project (PKP); SEER; Ambiente; Água.

\section{Buenas prácticas para la publicación científica}

\section{RESUMEN}

En este editorial, los principios de una publicación científica, los procedimientos editoriales y comunicación entre los autores y el Comité Editorial de la revista Ambiente \& Água se discuten con el fin de mejorar el flujo de publicación. Ambi-Agua es una revista de acceso totalmente abierto, sin cargos para sumisión, edición o publicación y se encuentra en una fase de consolidación, con sólo cinco años de circulación. Nuestro personal se limita a unas pocas personas que trabajan en tiempo parcial en la revista y tienen varias otras tareas 
impuestas por sus puestos de trabajo en la Universidad de Taubaté. El Instituto de Investigación Ambiental en Cuencas Hidrográficas (IPABHi) ha prestado apoyo financiero para cubrir el registro del doi ${ }^{\mathrm{TM}}$, del dominio de Internet y hosting del sistema electrónico de editoración. Por lo tanto, es importante que la comunicación se mantiene tan amable y eficiente para maximizar la productividad.

Palabras clave: Ambi-Agua, instrucciones a los autores; Open Journal Systems (OJS), Public Knowledge Project (PKP), SEER, Medio Ambiente y Agua.

\section{INTRODUCTION}

Scientific writing for publication in a journal that practices peer review and strives for high recognition in the scientific community is not an easy task and requires training and knowledge to be successful. First of all, the author has to have research results that effectively contribute to the advancement of science by introducing new approaches or significant knowledge about a theme related to the submitting journal interest. Therefore, after achieving its results based on solid scientific principles, the author should select the appropriate journal to submit his/her manuscript. At this phase the author should not only look at thematic considerations but also at the journal ranking and reputation, according to several indices (Batista, 2007). The author should try the most prestigious journals first and if the manuscript is not accepted should try other journals with lower rank, after it is definitively rejected by the previous journal (Volpato, 2008).

Several papers and books have been published to help an author to come up with a well written manuscript for publication. It is worth mentioning the books by Katz (2006) and Day and Gastel (2006). For those with Portuguese language domain books published by Volpato (2008 and 2011) and one published by Rey (1993) are recommended. Considering all technical aspects of the scientific and ethical writing described by these books, there are aspects concerning each journal in particular, that authors should observe; suggestions on how authors should relate with Ambiente \& Água Journal are described in the next session.

\section{AMBIENTE \& ÁGUA CONSIDERATIONS}

All submissions have to be made via the journal electronic editorial system by logging on with author's user name and password after registering. The main reason for that is that the corresponding author has to check several statements in order to proceed with his submission. Among those, a special one: "The contribution to be submitted to the journal is original and unpublished and not being evaluated for publication by another journal". This is very important and constitutes an author capital sin to submit the same manuscript to more than one journal at the same time or before it gets rejected by the previous journal. Another important statement to be checked is "As corresponding author, I declare that all authors have knowledge that I am submitting this manuscript for publication in the scientific journal Ambiente \& Água - An Interdisciplinary Journal of Applied Science and that they read and revised its final form and they agree with the submission, following all terms of the five steps above for submission". It is not expected changing authorship after manuscript submission. In addition, after submission each manuscript receives a number code and this will be always attached to the article, even after publication. All correspondence with the journal should always use this number and the manuscript title. This facilitates tremendously the Editor work.

Before deciding to submit a manuscript to Ambi-Agua journal it is essential that authors peruse the journal's site to get acquainted with the journal's indexations, Qualis CAPES classification, average time for publication, thematic interest of the journal and especially the 
author's guidelines for paper preparation and submission, avoiding unnecessary questions to the Editor. Authors have to realize that this is an interdisciplinary journal that covers a wide scope of themes in the environmental and water resource sciences and that it depends heavily on the expertise of the peer reviewers. Every submitted manuscript is evaluated by at least two ad hoc reviewers if it passes by the Editorial Committee preliminary evaluation. To be able to have two appropriate reviews, sometimes five or six ad hoc reviewers have to be consulted after careful analysis of their science production against the manuscript theme. We select very carefully the reviewers among prominent scientists. Usually they have a very tide up schedule to accept a voluntary, unexpected and demanding task. All this makes the time between submission and publication unpredictable. However, the quality of the manuscript makes much difference; reviewers tend to be motivated by well written texts.

Good practices include not only well written submissions, but also careful word processing care and attention, such as avoiding inserting tables in image format instead of text what would increase the file size and reduce quality. Figures should have well sorted out font sizes to be readable, with complete explanatory legend and good resolution with the smallest possible file size. They should never be pasted into the text but rather inserted as a separate archive.

\section{FINAL REMARKS}

Even though Ambi-Agua has a reduced staff that shares its activities with several other obligations, we always try to be responsive to author's inquiries. However, it is important that communication should be kept to a minimum needed for efficiency sake. In addition to get acquainted with the journal home page, it is important that potential authors read the editorials in as much as they explain the development of the journal throughout its history. We continue to be very appreciative of high standard submissions, especially in English to increase our journal impact factor.

\section{REFERENCES}

BATISTA, G. T. Scientific journal indexing. Ambi-Agua, Taubaté, v. 2, n. 2, p. 3-6, 2007. Available: <http://dx.doi.org/10.4136/ambi-agua.22>. Access: August, 2011.

DAY, R. A.; GASTEL, B. How to write and publish a scientific papers. 6. ed. Greenwood: Cambridge University Press, 2006. 320p.

KATZ, M. J. From research to manuscript: a guide to scientific writing. Dordrecht: Springer, 2006. 152p.

REY, L. Planejar e redigir trabalhos científicos. 2. ed. São Paulo: Edgard Blücher, 1993. 328p.

VOLPATO, G. Publicação científica. 3. ed. São Paulo: Cultura Acadêmica, 2008. 125p.

VOLPATO, G. L. Método lógico para redação científica. Botucatu: Best Writing, 2011. 320p. 